\title{
Enhancing bioassessment approaches: development of a river services assessment framework
}

\author{
Adam G. Yates ${ }^{1,2,7}$, Joseph M. Culp ${ }^{1,3,8}$, David G. Armanini ${ }^{1,2,9}$, Donald J. Baird ${ }^{1,4,10}$, \\ Timothy D. Jardine ${ }^{1,5,11}$, and Jessica M. Orlofske ${ }^{1,6,12}$ \\ ${ }^{1}$ Canadian Rivers Institute, 10 Bailey Drive, P.O. Box 4400, Fredericton, New Brunswick, Canada E3B 5A3 \\ ${ }^{2}$ Department of Geography, Western University, 1151 Richmond Street, London, Ontario, Canada N6A 5C2 \\ ${ }^{3}$ Environment and Climate Change Canada, Department of Biology, Wilfrid Laurier University, 75 University Avenue West, Waterloo, \\ Ontario, Canada N2L 3C5 \\ ${ }^{4}$ Environment and Climate Change Canada, Department of Biology, University of New Brunswick, 10 Bailey Drive, P.O. Box 4400, \\ Fredericton, New Brunswick, Canada E3B 5A3 \\ ${ }^{5}$ School of Environment and Sustainability and Toxicology Centre, University of Saskatchewan, 44 Campus Drive, Saskatoon, \\ Saskatchewan, Canada S7N 5C5 \\ ${ }^{6}$ Biological Sciences Department, University of Wisconsin-Parkside, 900 Wood Road, Kenosha, Wisconsin 53144 USA
}

\begin{abstract}
There has been a trend toward increasing anthropocentrism in definitions of river health through the explicit inclusion of societal valuation of ecosystem services provided by rivers. New frameworks and associated indicators of river health are therefore required to centralize ecosystem services within river assessment and management activities. Here, we adopt an anthropocentric conceptualization of rivers to focus on a river's ability to maintain ecological function and structure that support ecosystem services valued by society. We apply this approach to further existing conceptual models of river assessment by identifying how benthic indicators can be linked to valued ecosystem services in a river services assessment framework. This approach extends bioassessment from a focus on assessing departure from reference condition to also include the evaluation of rivers based on their delivery of ecosystem services. Indicators based on benthic processes and assemblages are widely used in river health assessments; thus, these are reviewed to identify those indicators most closely linked with the provision of river ecosystem services. Finally, we illustrate how our approach can be applied to management through contrasting watershed examples, including a highly modified agricultural region and relatively pristine Arctic watersheds. The proposed approach supports an explicit connection between valued ecosystem services and benthic indicators, providing more targeted assessment results for use in river management decision-making.
\end{abstract}

Key words: benthic indicators, ecosystem services, river assessment, river health, river management framework

Societies value healthy rivers (UNEP 2012) and invest significant funding to sustain them. In a recent study that explored the costs and benefits of river ecosystem maintenance, Feuillette et al. (2016), quoting Large (2008), noted that to restore 3 waterbodies in Normandy, France, €235 M was invested over 6 years, mostly in terms of recurrent costs. To support ongoing maintenance of river health, monitoring is considered essential and is actively practiced internationally, largely with freshwater benthic macroinvertebrates as the focus of assessment observations (e.g., Buss et al. 2015). A variety of approaches have been developed to evaluate biological monitoring data collected from rivers.
These approaches range from site-level summaries of taxonomic composition, often expressed as ecological indices (e.g., richness, diversity, ecological traits), to more complex modeling methods such as the reference condition approach, which ascertains site health by comparing ecological endpoints at target sites with those observed at appropriate minimally altered sites (Wright et al. 2000, Bailey et al. 2004, Hering et al. 2004, Stoddard et al. 2006). These approaches are strongly rooted within the concept of ecosystem integrity, where healthy river ecosystem sites are deemed to include all expected species and ecological functions (Frey 1977, Karr and Chu 1999). However, it is increasingly recog-

E-mail addresses: ${ }^{7}$ adam.yates@uwo.ca; ${ }^{8}$ joseph.culp@canada.ca; ${ }^{9}$ d.armanini@prothea.com; ${ }^{10}$ djbaird@unb.ca; ${ }^{11}$ tim.jardine@usask.ca; ${ }^{12}$ orlofske@uwp .edu

DOI: 10.1086/701674. Received 6 September 2017; Accepted 6 August 2018; Published online 8 February 2019.

Freshwater Science. 2019. 38(1):12-22. ๑ 2019 by The Society for Freshwater Science. 
nized that human values, needs, and institutions should be explicitly incorporated into any definition of health (e.g., Meyer 1997, Pahl-Wostl et al. 2013).

Recently, there has been a trend toward increasing anthropocentrism in definitions of river health through the explicit inclusion of societal valuation of ecosystem services provided by rivers (e.g., Vugteveen et al. 2006). Here, we adopt an anthropocentric conceptualization of rivers to focus on a river's ability to sustain ecological function and structure that support ecosystem services valued by society. This definition is more integrative and adaptable than river health definitions centered only on departure from reference condition or ecological integrity (sensu Karr and Chu 1999) and can be integrated into existing designated use frameworks and regulatory standards, such as those applied as part of the US Clean Water Act (CWA; 1972, and as amended, U.S. Code title 33, \$\$1251-1387). In this way, our definition encourages a fuller exploration of ecological status for all rivers, which, following careful testing and establishment of indicators, will lead to increased valuation of river systems that are inherently intertwined with human activities. Moreover, our conceptualization of river health enables a dynamic approach to defining the value of rivers, which could include ecological integrity, through explicit acknowledgement that values can change across time and space to fit the needs and priorities of stakeholders in any geographical and societal context. Thus, our definition empowers stakeholders to make more informed decisions about using rivers, such that managers can set regulatory standards that ensure all valued services that benefit society are maintained.

Freshwater, and particularly river, ecosystems are recognized as providing key ecosystem services under 4 categories: provisioning (food and water), regulating (flood control and water purification), supporting (nutrient cycling), and cultural (recreation; Covich et al. 2004a, MEA 2005). Delivery of ecosystem services and associated enhancement of human well-being have been conceptually linked with ecosystem functioning, which in turn depends on biodiversity (MEA 2005). Empirical demonstrations of the linkages between ecosystem services, ecosystem function, and biodiversity are rare (Covich et al. 2004a), in large part due to the complexity of the relations and, thus, the extensive quantitative data and analyses required. Nevertheless, there are an increasing number of studies showing at least modest correlations between ecosystem service delivery and biodiversity. For example, a study by Pinto et al. (2014) explicitly linked biodiversity, ecosystem functioning, and ecosystem services in benthic environments of estuarine systems.

Recognition that strong dependencies exist between the delivery of ecosystem services and different attributes of ecological function and structure present an opportunity to improve the capability of environmental monitoring and assessment to inform management of river health. For example, Reyjol et al. (2014) suggest the incorporation of river ecosystem services into the European Water Framework Directive could provide a common language that could allow all stakeholders to address their needs in river restoration activities. Our purpose is to develop a river services assessment framework that builds upon current, stressor-based river health indicators by relating river ecosystem services to indicators of ecological structure and function. Our approach explicitly connects valued ecosystem services with appropriate indicators, to provide more targeted assessments for use in river management decisionmaking. Paetzold et al. (2010) proposed a similar approach to assess ecosystem health through analysis of ecosystem service profiles, which they define as "the overlap between societal expectations for, and the sustainable provision of, suites of ecosystem services." Such analyses provide a means of gauging the current level of service delivery relative to societal expectations. We explore these ideas of river services through the lens of river benthos function and diversity because the benthos is a central ecosystem service provider in rivers.

The benthos possesses numerous structural and functional features that exemplify its central role in providing ecosystem services that underpin river health. The sediment-water interface is a biogeochemical hot spot, playing a disproportionate role in chemical transformations and biological productivity, especially in fast-flowing reaches where water column production and respiration are limited by short water retention times. In shallow, oxygenated waters, much of the total primary production occurs on submerged surfaces (Lamberti and Steinman 1997). In deeper, hypoxic waters, benthic habitats contain large reservoirs of detritus that fuel microbial productivity (Fischer and Pusch 2001) and associated nutrient transformations, including denitrification (Stief 2013). Moreover, benthic secondary production may be substantial (Benke 1998) and provide an energy source for higher trophic levels including fish and other wildlife. In addition, certain invertebrates that achieve large biomasses can modify their environment through processes of filtration and bioturbation (Vaughn and Hakenkamp 2001, Covich et al. 2004b). Benthic indicators of structure (e.g., percent sensitive taxa) and function (e.g., organic matter breakdown) have a history of use in river health assessment (Young and Collier 2009), but these indicators are typically measured without explicit consideration of how they link with ecosystem services.

Our primary aim is to build on existing conceptual models of river health by constructing a river services assessment framework that identifies how benthic indicators of ecological structure and function can be linked with valued ecosystem services. This approach extends bioassessment from the measurement of ecological integrity to include the assessment of the extent to which rivers provide differ- 
ent ecosystem services. Bioassessment indicators designed to measure benthic processes and taxonomic assemblages are widely used in river health assessments. We highlight those that offer potential as predictors of river ecosystem services. Finally, by providing contrasting examples of a watershed highly modified by agricultural and relatively pristine Arctic watersheds, we illustrate how our approach has broader application to ecosystem management.

\section{RIVER SERVICES ASSESSMENT FRAMEWORK}

Most rivers, especially those flowing through highly developed or urbanized landscapes, support a range of competing and ever-changing societal demands (Arthington et al. 2010). These demands may change rapidly and unpredictably through time. For example, erosion control and flood mitigation may be required seasonally, while the need for nutrient mitigation may increase over time associated with the expansion of urban and rural developments. Similarly, ecosystem service prioritization will vary geographically, with users expecting different services from headwaters and smaller tributaries than they do of larger tributaries and main stems. Therefore, it would be useful to prioritize the different ecosystem services desired from specific rivers within an adaptive management context that recognizes variable, shifting, and sometimes competing interests.

Our framework guides the evaluation and assessment of rivers by explicitly identifying connections between benthic indicators and river ecosystem services (Fig. 1). The initial step for monitoring and managing river ecosystem services involves identifying those river ecosystem services that stakeholders value and that improve or maintain human well-being (i.e., provisioning, regulating, supporting, or cultural; Hattam et al. 2015). This step parallels existing approaches used in Environmental Impact Assessment (EIA), such that ecosystem service delivery can be linked to valued ecosystem components (VECs) as part of the EIA process (e.g., Sinclair et al. 2017). Furthermore, just as elicitation of expert opinion and extensive public consultation are central to VEC selection, a similar process for selection of valued river ecosystem services can be employed (e.g., Hattam et al. 2015). Following identification of valued river ecosystem services, we propose an integrated, two-step process that links establishment of targeted provision levels with benthic indicator selection (Fig. 1). Specifically, stakeholders and managers would establish target provision levels for each valued service, and river scientists would select benthic indicators that best assess the status of those services.

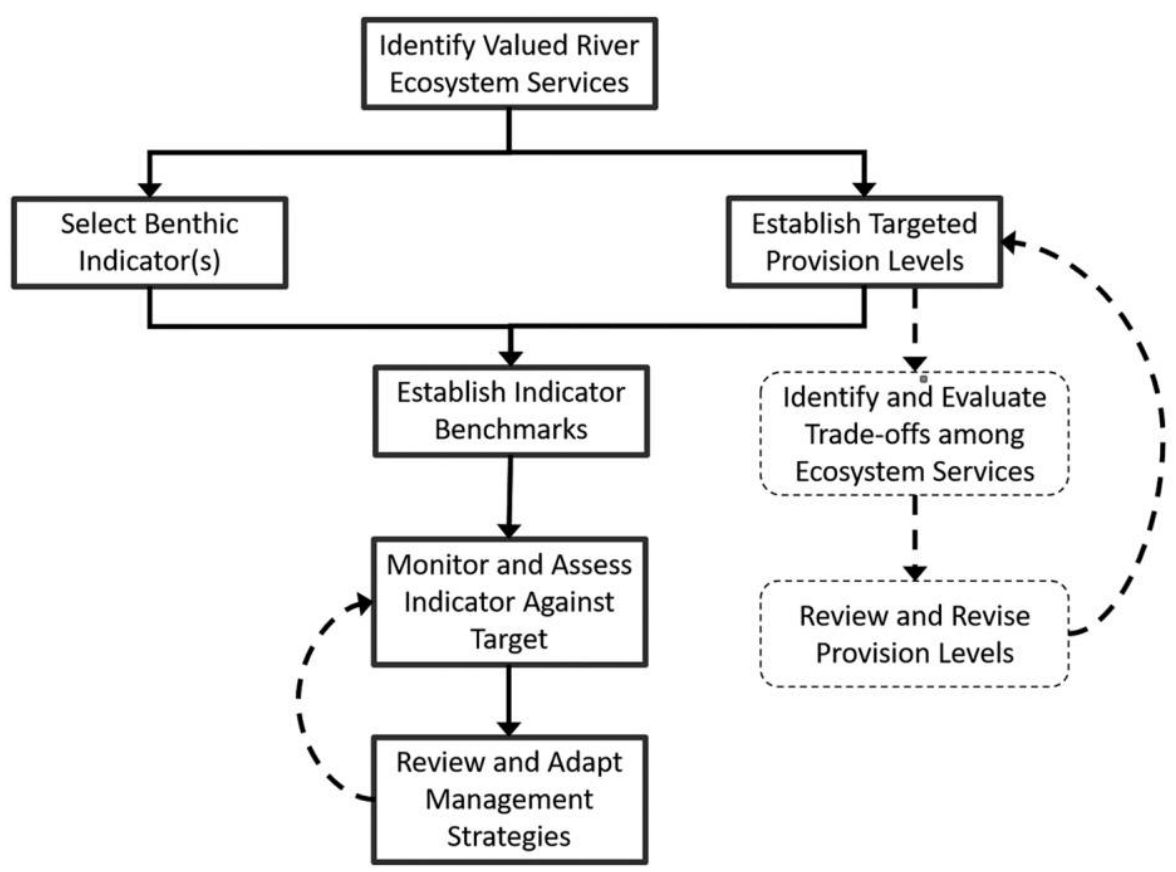

Figure 1. River services assessment framework illustrating how river ecosystem services could be used to enhance river health assessment. Valued river ecosystem services are identified by stakeholders who interact with managers and researchers to establish targeted provisioning levels. In doing this, potential trade-offs among ecosystem services are identified, informing an adaptive cycle of reviewing and revising target provision levels. Benthic indicators of ecological structure and function are selected and associated indicator benchmarks established based on relationships with targeted levels of service provision. Monitoring and assessment of indicators is then undertaken to determine whether system performance meets desired provision levels. Results of indicator assessments are used to inform a cycle of review and adaptation of river management strategies to achieve ecosystem service targets. 
Decisions regarding establishment of target provision levels of ecosystem services will necessarily be driven by shifting, and possibly competing, societal needs and demands (Fig. 1). In fact, the optimization of one service can influence the physical and biological processes that provide and maintain other services (Helfenstein and Kienast 2014). Moreover, trade-offs in ecosystem services (Bennett et al. 2009) that support societal use and maintain ecosystem quality may result in ecosystem disservices, that is, enhancements in one or more ecological services that reduce or impair the capacity of the system to provide other ecosystem services. These trade-offs have the potential to cause an overall net reduction of benefits at an ecosystem scale. For example, bioturbation from native and invasive fish and crayfish (e.g., Asian Carp and red swamp crayfish) can stimulate sediment nutrient release, potentially enhancing ecosystem productivity. However, bioturbation may also release toxic contaminants stored in the sediment and reduce water quality, which can inhibit production of valued aquatic resources (Matsuzaki et al. 2009, Fischer et al. 2013). Similarly, the production of aquatic plants could be used to sequester excess nutrients, but the increased biomass of plants may restrict water and sediment transport and reduce dissolved oxygen concentrations (Caraco and Cole 2002). Thus, identification and evaluation of tradeoffs among ecosystem services, and their potential unintended consequences, will be a necessary part of an iterative, ecosystem service-based approach to river monitoring and management (Fig. 1). This process would follow from employment of expert approximation of river ecosystem services values and conditions as described by Helfenstein and Kienast (2014). Importantly, our framework allows for the simultaneous assessment of the status of multiple river ecosystem services. Therefore, in cases where more than one river ecosystem service is valued, the approach permits managers to evaluate the relative and collective benefits produced from management actions that target different ecosystem services. This approach allows for an adaptive management cycle, where measured trade-offs between different ecosystem services inform the iterative review and revision of targeted provisioning levels.

Alterations of ecosystem services and VECs can be very difficult to detect and monitor (Wood et al. 2000). Our approach addresses this challenge by directly linking the indicator with the service of interest (Fig. 1). We propose that benthic ecologists could provide a suite of indicators to assess the status of valued river ecosystems services. Associations between benthic indicators and service provision would then be quantified and used to establish indicator benchmarks that represent targeted provision levels. The selected benthic indicators would be monitored to enable assessment of each indicator against the established indicator benchmark. Assessment results would then inform a cycle of review and adaptation of river management strate- gies for achievement of ecosystem service targets. This review process could include causal investigations that would determine the stressors responsible for preventing attainment of targeted provision levels.

\section{BENTHIC INDICATORS OF ECOSYSTEM SERVICES}

Our river services assessment framework incorporates indicators that directly link with the ecosystem services that society values from a given river system (Table 1). These ecosystem services include commercial, subsistence, and recreational fisheries; water purification; primary production; decomposition; pest/disease control; and erosion control (MEA 2005). The benthos of rivers directly and indirectly support many of these valued ecosystem services by providing a source of food and habitat for other organisms and by contributing to biogeochemical cycling, contaminant removal, disease suppression, and geomorphic stability. Accordingly, many existing measures of benthic function and structure could be useful as indicators of the status of river ecosystem services. For example, benthic organisms enhance and maintain fisheries through their role as food sources (Wallace and Webster 1996). Key properties of the benthic community known to be linked with fishery profitability and sustainability, such as biomass, diversity (taxonomic and trait), and stability (Pinto et al. 2014), could therefore be informative as indicators of probable and realized impacts of past management decisions. Similarly, many benthic organisms, including bivalves and macrophytes, play a role in purifying river water by assimilating nutrients and contaminants. This ecosystem service provides clean water for irrigation, agriculture, and human consumption, while disposing of wastes. Nevertheless, an important limitation to the adoption of our framework for river service assessment is the limited understanding of mechanistic connections among specific ecosystem services, ecological function, and biodiversity.

Our approach of centering river health management on ecosystem services incorporates the flexibility to allow application across a range of stakeholder priorities and rivers of contrasting ecological status. For example, in the Canadian Arctic, climate change and associated environmental effects on largely pristine streams and rivers are a threat to subsistence harvesting of fish and other aquatic wildlife (e.g., waterfowl) by indigenous peoples. In this case, protection of the natural diversity and resilience of these rivers is the primary goal. In contrast, in situations where rivers have a long history of intense human manipulation, the valued ecosystem services may be quite different. For example, in the Red River valley of southern Manitoba, societal development has focused on enhancing water transport and, most recently, water purification as the most valued services of streams and rivers. An advantage of our framework is that, despite the stark contrast in the two examples, 


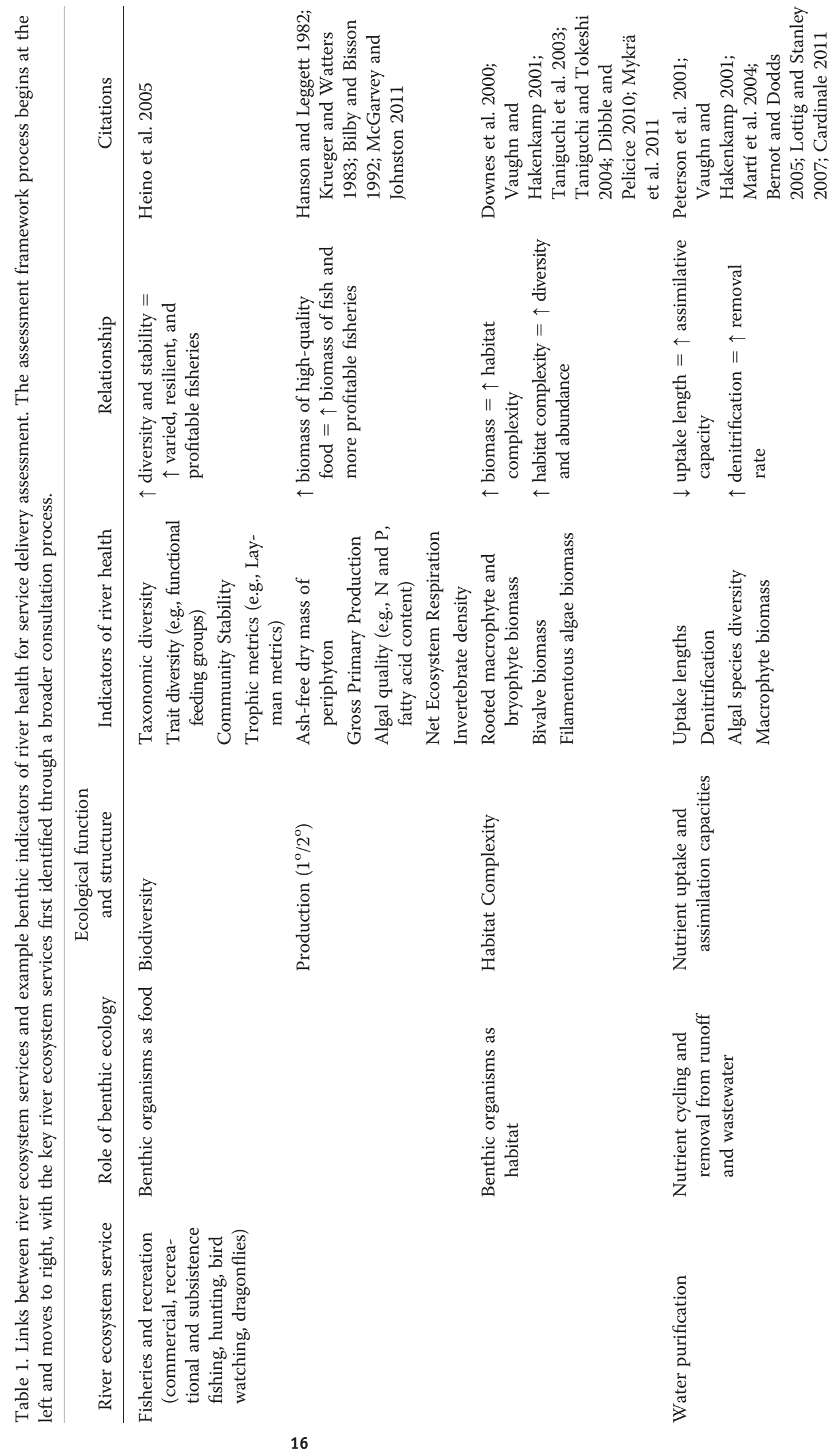




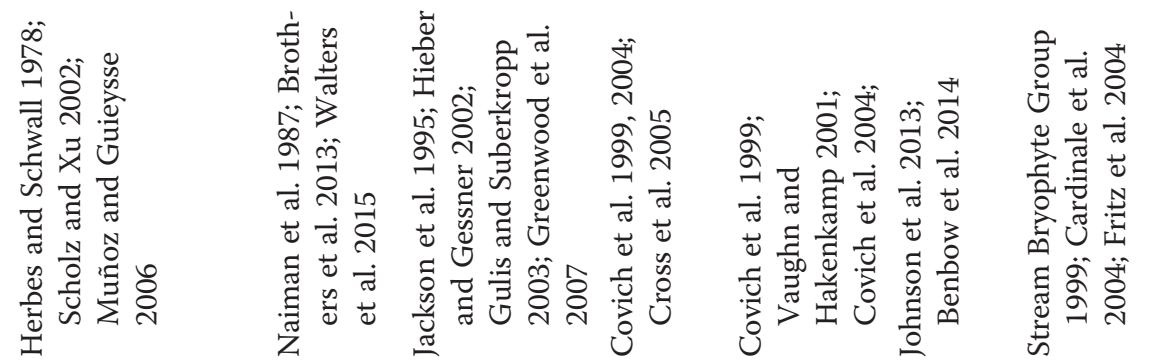

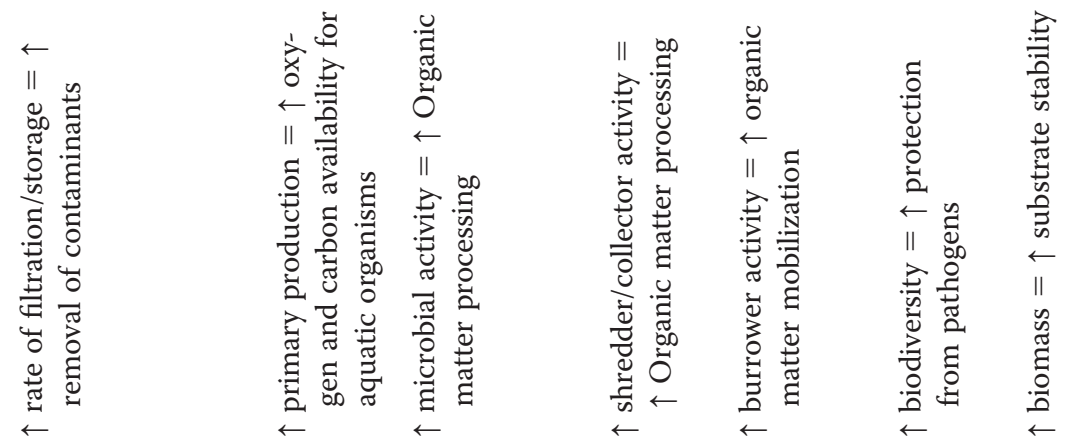

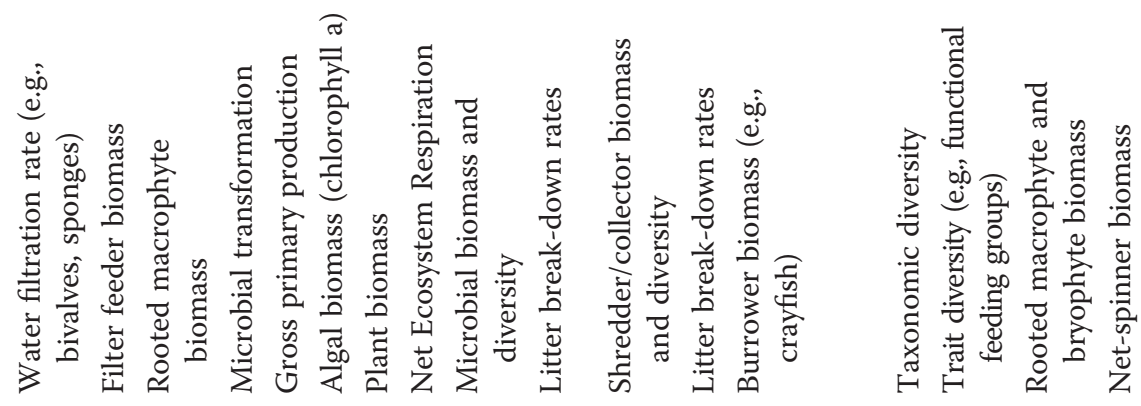
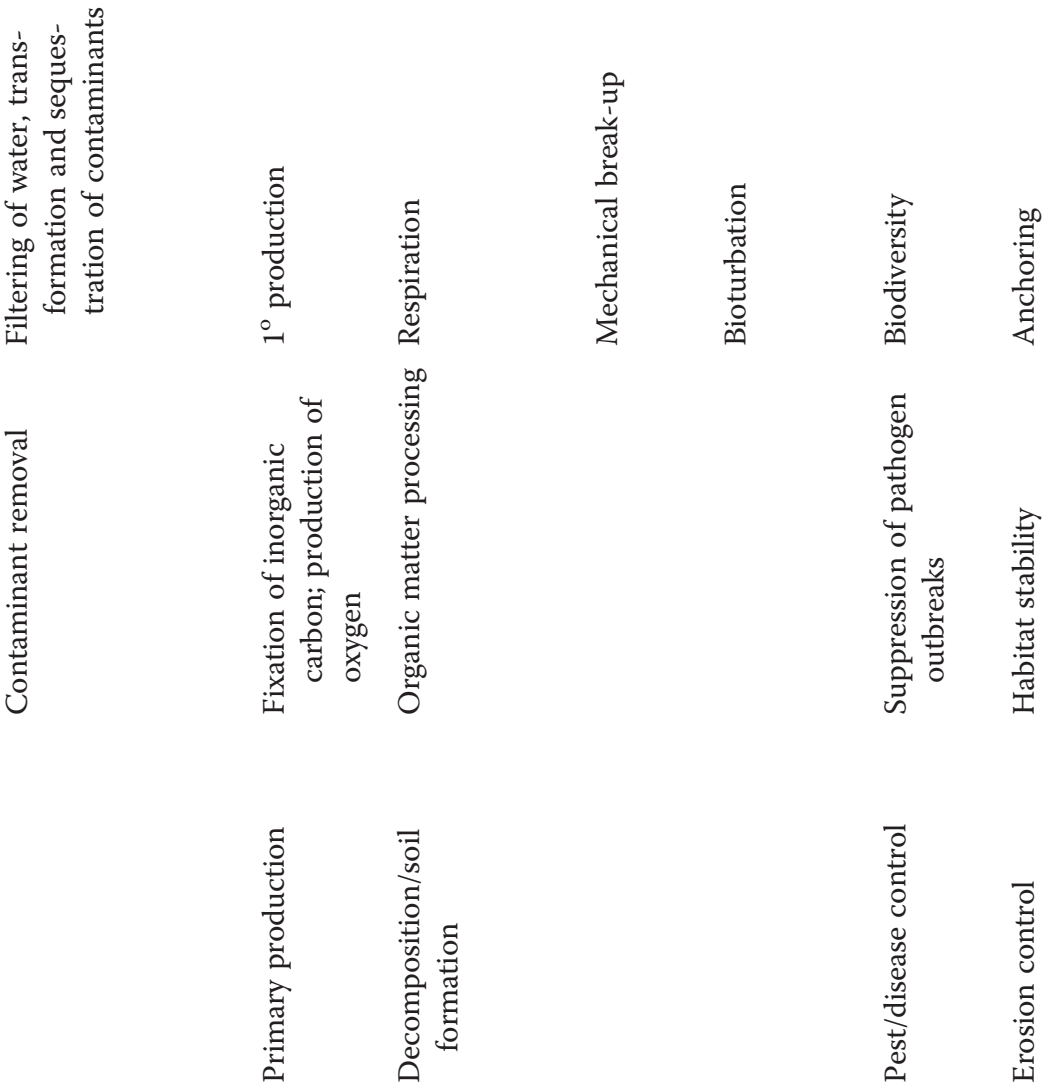
it can accommodate both scenarios by focusing indicator selection and associated assessment benchmarks on the valued services of the system.

The River Ecosystem Services Framework aligns with criteria put forward in recent calls to apply procedures, such as defining goals depending on context, developed for the medical sciences (e.g., Elosegi et al. 2017). In particular, the framework encourages setting standards and applying appropriate indicators that are individualized for river systems based on optimizing desired ecosystem services. Depending on societal and institutional goals, such indicators and standards could be traditional measures of ecological integrity based on biodiversity or ecological function at pristine reference sites. Alternatively, river health objectives may be focused on providing services that do not necessarily require maintenance of pristine reference conditions. Our approach would be especially advantageous for riverine ecosystem management where human uses of rivers are pervasive and reference conditions are absent, which challenges managers to identify appropriate benchmarks (Davies and Jackson 2006; Stoddard et al. 2006). Even where suitable proxies for pristine conditions exist, it is arguable whether river management based on departure from reference conditions is practical in contexts where rivers serve multiple, often conflicting, socioeconomic functions. Indeed, assessments based on absolute or tiered departure from reference conditions (e.g., biological condition gradient (Davies and Jackson 2006), European Water Framework Directive (WFD; 2000/60/EC) have the potential to undervalue existing functions of working rivers (i.e., rivers that are managed to accommodate a broad range of human uses) by highlighting degradation rather than functionality. Moreover, in situations where return to reference conditions may be impractical, managers and regulators may be frustrated by assessments that provide a lengthy list of impairments that cannot be fixed. Our framework emphasizes a river's capability to support valued ecosystem services and thus provides a path forward for more informed management of these anthropogenic river systems.

Implementation of our framework into monitoring, assessment, and management of river health requires research to address existing knowledge gaps regarding the processes and controls through which benthic communities and processes link to ecosystem services. For example, Bernhardt et al. (2018) describe how studies spanning multiple spatiotemporal scales are needed to establish the interactive relationships between nutrient cycling and river metabolism as well as the external controls on that relationship. Establishing empirical links between ecosystem services and both biodiversity and ecosystem functions will be critical for validating the potential use of the many benthic indicators described in our paper. Establishing indicator-service relationships will also be needed to identify indicator benchmarks that reveal whether desired levels of ecosystem ser- vices have been achieved for individual river systems. As discussed by Feld et al. (2010), benchmarks related to desired service levels are required to enable objective assessment of temporal and spatial trends in those services. Setting river ecosystem services benchmarks is currently hindered by limited understanding of the relationship between benefits to human well-being and service provision. Moreover, there is a need to generate models that can predict how service provision is likely to be affected by future climate and land use changes (Schernewski et al. 2018). Such models would enhance adaptive management by allowing decision makers to set service target levels that align with societal and institutional goals for human well-being.

\section{ILLUSTRATION OF HOW THE FRAMEWORK CAN BE APPLIED \\ Case study 1: Arctic freshwaters}

The biodiversity of Arctic freshwater ecosystems is increasingly threatened by climate change and human development (Heino et al. 2009). Changes in the physical and chemical properties of freshwater systems that will result from modified water temperature, and ice cover regimes, thawing permafrost, and changes to hydrological processes are all expected to directly affect ecosystem structure and function (Culp et al. 2012). Arctic countries through the Circumpolar Biodiversity Monitoring Program (CBMP) have developed monitoring approaches that would measure shifts in freshwater biodiversity. The CBMP defines ecologically pivotal focal ecosystem components for lakes and rivers, such as the benthos, as central parameters for the monitoring approach.

The CBMP monitoring framework for arctic rivers could be enhanced by using our framework (Fig. 1) to assess and maintain river health in the face of a changing climate. In this case, a valued ecosystem service is the provision of sustaining fish biomass for subsistence fisheries. Because of the difficulty in accurately assessing fish populations in a timely manner, indigenous communities could set target provision levels to be assessed with benthic indicators of the amount and type of food available to fish (e.g., invertebrate diversity and abundance; Table 1). A benefit of applying the framework in this case arises from the ability to provide stakeholders with simple indicators that can measure the status and trends of ecosystem components directly related to fisheries. Assessment of these indicators could inform future management decisions to protect traditional fishing grounds and maintain ecological resilience.

\section{Case study 2: Red River Valley}

Lake Winnipeg is the $10^{\text {th }}$ largest lake in the world and, like many such ecosystems in close proximity to large human populations, has undergone rapid eutrophication in the 
past 2 decades (Schindler et al. 2012). Recent water quality monitoring has identified that the major source of nutrients entering Lake Winnipeg come from tributaries draining the Red River watershed. As a result, there has been strong interest in assessing and managing the conditions of Red River tributaries as both a cause and potential solution to Lake Winnipeg's eutrophication problem. The catchments of Red River tributaries are intensively managed for agricultural production (Yates et al. 2012), and much of the channel network was historically modified to enhance water transport supporting agricultural drainage.

As such, a key valued ecosystem service of these rivers is water transport. However, with growing concern regarding Lake Winnipeg, there is also an interest in managing these streams to enhance water purification services to reduce nutrient losses associated with agricultural runoff to downstream ecosystems. Applying our framework for river health assessment (Fig. 1) to the Red River Valley would entail identifying indicators associated with water purification. As outlined in Table 1, direct measurements of nutrient processing would include denitrification rates and nutrient uptake lengths, whereas indirect measures could include gross primary production and biomass of primary producers. River services related to water transport of floodwaters would not be expected to be enhanced through improved benthic diversity or function. For example, nutrient removal and assimilation might be maximized by 1) slowing water travel times to increase exposure to sediments and 2) maximizing plant growth to retain nutrients. Both of these actions could negatively affect water transport because excess macrophyte biomass can restrict water flow. Managers would thus need to balance the trade-offs between nutrient processing and water transport by applying our proposed framework iteratively through scenario modeling or adaptive management strategies (Fig. 1) to find the balance that most benefits society.

\section{SUMMARY}

In this paper we have built on existing definitions and frameworks of river assessment and have explicitly linked ecosystem services with benthic function and structure. By focusing on a river's ability to support valued ecosystem services through the maintenance of ecological function and structure, we were able to construct a novel framework incorporating powerful adaptive management cycles that can be applied for the assessment of river ecosystems. The proposed framework would lead to identifying explicit connections between valued river ecosystem services and benthic indicators, thereby providing more targeted assessment results for use in river management. An important advantage is the capability to simultaneously assess management actions aimed at different and potentially conflicting river uses. Additionally, we have provided a suite of benthic indica- tors that should undergo future testing to establish the empirical connection between these measures of benthic structure and function and the valued river ecosystem service of interest. Our emphasis on a river's ability to support ecosystem services valued by society is unashamedly anthropocentric, and indeed it was our explicit purpose to recognize that all rivers, from free-flowing wild rivers to canalized waterways, are managed for human uses. This strong connection between societal requirements and river ecosystem management leads us to believe that our framework can support explicit recognition of the benefits society receives from river ecosystem services and can encourage more systematic management of river futures.

\section{ACKNOWLEDGEMENTS}

Author contributions: All authors contributed to the conception of the problem, the proposed approach, manuscript preparation, and editing.

We thank the Canadian Rivers Institute, which conceived and organized the River Health Workshop where the paper was initiated. The travel costs of AGY, JMC, and TDJ were partially funded through Individual Discovery Grants from the Natural Sciences and Engineering Research Council of Canada. We thank Sarah McKenzie for assistance with literature review. We also thank the anonymous reviewers for their constructive criticisms.

\section{LITERATURE CITED}

Arthington, A. H., R. J. Naiman, M. E. McClain, and C. Nilsson. 2010. Preserving the biodiversity and ecological services of rivers: new challenges and research opportunities. Freshwater Biology 55:1-16.

Bailey, R. C., R. H. Norris, and T. B. Reynoldson. 2004. Bioassessment of freshwater ecosystems using the reference condition approach. Kluwer Academic Publishers, Boston, Massachusetts.

Benbow, M. E., R. Kimbirauskas, M. D. McIntosh, H. Williamson, C. Quaye, D. Boakye, P. L. C. Small, and R. C. Merritt. 2014. Aquatic macroinvertebrate assemblages of Ghana, West Africa: understanding the ecology of a neglected tropical disease. EcoHealth 11:168-183.

Benke, A. C. 1998. Production dynamics of riverine chironomids: extremely high biomass turnover rates of primary consumers. Ecology 79: 899-910.

Bennett, E. M., G. D. Peterson, and L. J. Gordon. 2009. Understanding relationships among multiple ecosystem services. Ecology Letters 12:1394-1404.

Bernhardt, E. S., J. B. Heffernan, N. B. Grimm, E. H. Stanley, J. W. Harvey, M. Arroita, A. P. Appling, M. J. Cohen, W. H. McDowell, R. O. Hall, J. S. Read, B. J. Roberts, E. G. Stets, and C. B. Yackulic. 2018. The metabolic regimes of flowing waters. Limnology and Oceanography 63:S99-S118.

Bernot, M. J., and W. K. Dodds. 2005. Nitrogen retention, removal, and saturation in lotic ecosystems. Ecosystems 8:442-453.

Bilby, R. E., and P. A. Bisson. 1992. Allochthonous versus autochthonous organic matter contributions to the trophic support of fish populations in clear-cut and old-growth forested streams. Canadian Journal of Fisheries and Aquatic Sciences 49:540-551. 
Brothers, S. M., S. Hilt, S. Meyer, J. Köhler. 2013. Plant community structure determines primary productivity in shallow, eutrophic lakes. Freshwater Biology 58:2264-2276.

Buss, D. F., D. M. Carlisle, T. Chon, J. Culp, J. S. Harding, H. E. Keizer-Vlek, W. A. Robinson, S. Strachan, C. Thirion, and R. M. Hughes. 2015. Stream biomonitoring using macroinvertebrates around the globe: a comparison of large-scale programs. Environmental Monitoring and Assessment 187: 4132.

Caraco, N. F., and J. J. Cole. 2002. Contrasting impacts of a native and alien macrophyte on dissolved oxygen in a large river. Ecological Applications 12:1496-1509.

Cardinale, B. J. 2011. Biodiversity improves water quality through niche partitioning. Nature 472:86-99.

Cardinale, B. J., E. R. Gelmann, and M. A. Palmer. 2004. Net spinning caddisflies as stream ecosystem engineers: the influence of Hydropsyche on benthic substrate stability. Functional Ecology 18:381-387.

Covich, A. P., M. C. Austen, F. Bärlocher, E. Chauvet, B. J. Cardinale, C. L. Biles, P. Inchausti, O. Dangles, M. Solan, M. O. Gessner, B. Statzner, and B. Moss. 2004a. The role of biodiversity in the functioning of freshwater and marine benthic ecosystems. BioScience 54:767-775.

Covich, A. P., K. C. Ewel, R. O. Hall, P. S. Giller, W. Goedkoop, and D. M. Merritt. 2004b. Ecosystem services provided by freshwater benthos. Pages 45-71 in D. W. Wall (editor). Sustaining biodiversity and ecosystem services in soils and sediments. Island Press, Washington, DC.

Covich, A. P., M. A. Palmer, and T. A. Crowl. 1999. The role of benthic invertebrate species in freshwater ecosystems: zoobenthic species influence energy flows and nutrient cycling. BioScience 49:119-127.

Cross, W. F., J. P. Benstead, P. C. Frost, S. A. Thomas. 2005. Ecological stoichiometry in freshwater benthic systems: recent progress and perspectives. Freshwater Biology 50:1895-1912.

Culp, J. M., J. Lento, W. Goedkoop, M. Power, M. Rautio, K. S. Christoffersen, G. Guðbergsson, D. Lau, P. Liljaniemi, S. Sandøy, and M. Svoboda. 2012. Developing a circumpolar monitoring framework for Arctic freshwater biodiversity. Biodiversity 13:215-227.

Davies, S. P., and S. K. Jackson. 2006. The biological condition gradient: a descriptive model for interpreting change in aquatic ecosystems. Ecological Applications 16:1251-1266.

Dibble, E. D., and F. M. Pelicice. 2010. Influence of aquatic plantspecific habitat on an assemblage of small Neotropical floodplain fishes. Ecology of Freshwater Fish 19:381-389.

Downes, J. B., S. P. Lake, G. E. S. Schreiber, and A. Glaister. 2000. Habitat structure, resources and diversity: the separate effects of surface roughness and macroalgae on stream invertebrates. Oecologia 123:569-581.

Elosegi, A., M. O. Gessner, and R. G. Young. 2017. River doctors: learning from medicine to improve ecosystem management. Science of the Total Environment 595:294-302.

Feld, C. K., J. P. Sousa, P. Martins da Silva, and T. P. Dawson. 2010. Indicators for biodiversity and ecosystem services: towards an improved framework for ecosystems assessment. Biodiversity Conservation 19:2895-2919.

Feuillette, S., H. Levrel, B. Boeuf, S. Blanquart, O. Gorin, G. Monaco, B. Penisson, and S. Robichon. 2016. The use of cost-ben- efit analysis in environmental policies: some issues raised by the Water Framework Directive implementation in France. Environmental Science and Policy 57:79-85.

Fischer, H., and M. Pusch. 2001. Comparison of bacterial production in sediments, epiphyton and the pelagic zone of a lowland river. Freshwater Biology 46:1335-1348.

Frey D. G. 1977. Biological integrity of water: an historical approach. Pages 127-140 in The integrity of water. Proceedings of a symposium. US Environmental Protection Agency, Washington, DC.

Fritz, K. M., M. M. Gangloff, and J. W. Feminella. 2004. Habitat modification by the stream macrophyte Justicia americana and its effects on biota. Oecologia 140:388-397.

Greenwood, J. L., A. D. Rosemond, J. B. Wallace, W. F. Cross, and H. S. Weyers. 2007. Nutrients stimulate leaf breakdown rates and detritivore biomass: bottom-up effects via heterotrophic pathways. Oecologia 151:637-649.

Gulis, V., and K. Suberkropp. 2003. Interactions between stream fungi and bacteria associated with decomposing leaf letter at different levels of nutrient availability. Aquatic Microbial Ecology 30:149-157.

Hanson, J. M., and W. C. Leggett. 1982. Empirical prediction of fish biomass and yield. Canadian Journal of Fisheries and Aquatic Sciences 39:257-263.

Hattam, C., J. P. Atkins, N. Beaumont, T. Börger, A. BöhnkeHenrichs, D. Burdon, R. de Groot, E. Hoefnagel, P. A. L. D. Nunes, J. Piwowarczyk, S. Sastre, and M. C. Austen. 2015. Marine ecosystem services: linking indicators to their classification. Ecological Indicators 49:61-75.

Heino, J., R. Paavola, R. Virtanen, and T. Muotka. 2005. Searching for biodiversity indicators in running waters: do bryophytes, macroinvertebrates, and fish show congruent diversity patterns? Biodiversity and Conservation 14:415-428.

Heino, J., R. Virkkala, and H. Toivonen. 2009. Climate change and freshwater biodiversity: detected patterns, future trends and adaptations in northern regions. Biological Reviews 84:3954.

Helfenstein, J., and F. Kienast. 2014. Ecosystem service state and trends at the regional to national level: a rapid assessment. Ecological Indicators 36:11-18.

Herbes, S. E., and L. R. Schwall. 1978. Microbial transformation of polycyclic aromatic hydrocarbons in pristine and petroleumcontaminated sediments. Applied and Environmental Microbiology 35:306-316.

Hering, D., O. Moog, L. Sandin, and P. F. M. Verdonschot. 2004. Overview and application of the AQEM assessment system. Hydrobiologia 516:1-20.

Hieber, M., and M. O. Gessner. 2002. Contribution of stream detritivores, fungi, and bacteria to leaf breakdown based on biomass estimates. Ecology 83:1026-1038.

Jackson, C. R., C. M. Foreman, and R. L. Sinsabaugh. 1995. Microbial enzyme activities as indicators of organic matter processing rates in a Lake Erie coastal wetland. Freshwater Biology 34: 329-342.

Johnson, P. T. J., D. L. Preston, J. T. Hoverman, and K. L. D. Richgels. 2013. Biodiversity decreases disease through predictable changes in host community competence. Nature 494:230-233.

Karr, J. R., and E. W. Chu. 1999. Restoring life in running waters: better biological monitoring. Island Press, Washington, DC. 
Krueger, C. C., and T. F. Waters. 1983. Annual production of macroinvertebrates in three streams of different water quality. Ecology 64:840-850.

Lamberti, G. A., and A. D. Steinman. 1997. A comparison of primary production in stream ecosystems. Journal of the North American Benthological Society 16:95-104.

Large, A. 2008. Justification des dérogations économiques à l'atteinte du bon état des eaux en Seine-Normandie. Approaches à différentes échelles. Memoire de DEA, Sup Agro, Montpellier, France.

Lottig, N. R., and E. H. Stanley. 2007. Benthic sediment influence on dissolved phosphorus concentrations in a headwater stream. Biogeochemistry 84:297-309.

Martí, E., J. Aumatell, L. Godé, M. Poch, and F. Sabater. 2004. Nutrient retention efficiency in streams receiving inputs from wastewater treatment plants. Lournal of Environmental Ouality 33:285-293.

Matsuzaki, N. U., N. Takamura, and I. Washitani. 2009. Contrasting impacts of invasive engineers on freshwater ecosystems: an experiment and meta-analysis. Oecologia 158:673-686.

McGarvey, D. J., and J. M. Johnston. 2011. A simple method to predict regional fish abundance: an example in the McKenzie River Basin, Oregon. Fisheries 36:534-546.

Meyer, J. L. 1997. Stream health: incorporating the human dimension to advance stream ecology. Iournal of the North American Benthological Society 16:439-447.

MEA (Millennium Ecosystem Assessment). 2005. Ecosystems and human well-being: synthesis. Island Press, Washington, DC.

Muñoz, R., and B. Guieysse. 2006. Algal-bacterial processes for the treatment of hazardous contaminants: a review. Water Research 40:2799-2815.

Mykrä, H., J. Heino, J. Oksanen, and T. Muotka. 2011. The stability-diversity relationship in stream macroinvertebrates: influences of sampling effects and habitat complexity. Freshwater Biology 56:1122-1132.

Naiman, R. J., J. M. Melillo, M. A. Lock, T. E. Ford, and S. R. Reice. 1987. Longitudinal patterns of ecosystem processes and community structure in a subarctic river continuum. Ecology 68: 1139-1156.

Paetzold, A., P. H. Warren, and L. L. Maltby. 2010. A framework for assessing ecological quality based on ecosystem services. Ecological Complexity 7:273-281.

Pahl-Wostl, C., A. Arthington, J. Bogardi, S. E. Bunn, H. Hoff, L. Lebel, E. Nikitina, M. Palmer, L. N. Poff, K. Richards, M. Schluter, R. Schulze, A. St-Hilaire, R. Tharme, K. Tockner, and D. Tsegai. 2013. Environmental flows and water governance: managing sustainable water use. Current Opinion in Environment and Sustainability 5:341-351.

Peterson, B. J., W. M. Wollheim, P. J. Mulholland, J. R. Webster, J. L. Meyer, J. L. Tank, E. Martí, W. B. Bowden, H. M. Valett, A. E. Hershey, W. H. McDowell, W. K. Dodds, S. K. Hamilton, S. Gregory, and D. D. Morrall. 2001. Control of nitrogen export from watersheds by headwater streams. Science 292:86-90.

Pinto, R., V. N. de Jonge, and J. C. Marques. 2014. Linking biodiversity indicators, ecosystem functioning, provision of services and human well-being in estuarine systems: application of a conceptual framework. Ecological Indicators 36:644-655.

Reyjol, Y., C. Argillier, W. Bonne, A. Borja, A. D. Buijse, A. C. Cardoso, M. Daufresne, M. Kernan, M. T. Ferreira, S. Poikane, and N. Prat. 2014. Assessing the ecological status in the context of the European Water Framework Directive: where do we go now? Science of the Total Environment 497:332344.

Schernewski, G., M Inácio, and Y. Nazemtseva. 2018. Expertbased ecosystem service assessment in coastal and marine planning and management: a Baltic lagoon case study. Frontiers in Environmental Science 6:1-14.

Schindler, D. W., R. E. Hecky, and G. McCullough. 2012. The eutrophication of Lake Winnipeg: greening under global change. Journal of Great Lakes Research 38:6-13.

Scholz, M., and J. Xu. 2002. Comparison of constructed reed beds with different filter media and macrophytes treating urban stream water contaminated with lead and copper. Ecological Engineering 18:385-390.

Sinclair, A. J., M. Doelle, and P. N. Duinker. 2017. Looking up, down, and sideways: reconceiving cumulative effects assessment as a mindset. Environmental Impact Assessment Review 62:183-194.

Stief, P. 2013. Stimulation of microbial nitrogen cycling in aquatic ecosystems by benthic macrofauna: mechanisms and environmental implications. Biogeosciences 10:7829-7846.

Stoddard, J. L., D. P. Larsen, C. P. Hawkins, R. K. Johnson, and R. H. Norris. 2006. Setting expectations for the ecological condition of streams: the concept of reference condition. Ecological Applications 16:1267-1276.

Stream Bryophyte Group. 1999. Roles of bryophytes in stream ecosystems. Iournal of the North American Benthological Society 18:151-184.

Taniguchi, H., S. Nakano, and M. Tokeshi. 2003. Influences of habitat complexity on the diversity and abundance of epiphytic invertebrates on plants. Freshwater Biology 48:718-728.

Taniguchi, H., and M. Tokeshi. 2004. Effects of habitat complexity on benthic assemblages in a variable environment. Freshwater Biology 49:1164-1178.

UNEP (United Nations Environment Programme). 2012. Healthy waters for sustainable development. UNEP operational strategy for freshwater (2012-2016). UNON Publishing Services Section, Nairobi, Kenya.

Vaughn, C. C., and C. C. Hakenkamp. 2001. The functional role of burrowing bivalves in freshwater ecosystems. Freshwater Biology 46:1431-1446.

Vugteveen, P., R. S. E. W. Leuven, M. A. J. Huijbregts, and H. J. R. Lenders. 2006. Redefinition and elaboration of river ecosystem health: perspective for river management. Pages 289308 in R. S. E. W. Leuven, A. M. J. Ragas, A. J. M. Smits, and G. van der Velde (editors). Living rivers: trends and challenges in science and management, Springer, Netherlands.

Wallace, J. B., and J. R. Webster. 1996. The role of macroinvertebrates in stream ecosystem function. Annual Review of Entomology 41:115-139.

Walters, D. M., D. F. Raikow, C. R. Hammerschmidt, M. G. Mehling, A. Kovach, and J. T. Oris. 2015. Methylmercury bioaccumulation in stream food webs declines with increasing primary production. Environmental Science and Technology 49:7762-7769.

Wood, C., B. Dipper, and C. Jones. 2000. Auditing the assessment of the environmental impacts of planning projects. Iournal of Environmental Planning and Management 43:23-47. 
A. G. Yates et al.

Wright, J. F., D. W. Sutcliffe, and M. T. Furse. 2000. Assessing the biological quality of freshwaters: RIVPACS and other techniques. Freshwater Biological Association, Ambleside, UK.

Yates, A. G., J. M. Culp, and P. A. Chambers. 2012. Estimating nutrient emissions from human activities to subcatchments of the Red River, Manitoba. Journal of Great Lakes Research 38:106-114.

Young, R. G., and K. J. Collier. 2009. Contrasting responses to catchment modification among a range of functional and structural indicators of river ecosystem health. Freshwater Biology 54:2155-2170. 